\title{
THE EFFECT OF SLEEP DEPRIVATION ON SERUM IGG RESPONSES TO AEROBIC ACTIVITY IN COLLEGE STUDENT ATHLETES
}

Saeed Jamshidi Far ${ }^{1}$, Mirza Hossein Norouzi Kamareh ${ }^{2}$

University of Guilan, Guilan, Iran ${ }^{1}$

University Razi, Kermanshah, $\operatorname{Iran}^{2}$

Annotation. Background \& Aims: Sleep is a restorative process for the immune system. There are many situations in which sleep is disturbed prior to an athletic event. However, the effect of sleep deprivation on immune indices in response to exercise remains unknown. The aim of this study was to investigate the effects of sleep deprivation on serum IgG responses to aerobic activity. Materials \& Methods: In this quasi-experimental study, 10 male physical education students were voluntarily participated. Study was performed in two separate occasions; control and experimental within two weeks. In the control occasion, normal sleep and aerobic activity and in the experimental occasion, sleep deprivation and aerobic activity was applied. Aerobic activity was performed on bicycle ergometer for 30 minutes at intensity of 70 to 75 percent of maximum heart rate. Changes in serum IgG concentrations in pre-test, before and after aerobic activity in both occasions were analyzed by the two repeated measures ANOVA and dependent T-test using SPSS software. Results: The results showed that sleep deprivation not significantly effect on Serum IgG response to aerobic activity $(\mathrm{p}=0.130)$. Also, aerobic activity not significantly effect on Serum $\operatorname{IgG}$ concentration $(\mathrm{p}=0.357)$. But sleep deprivation caused a significantly increase in serum IgG concentration $(\mathrm{p}=0.035)$. Conclusion: No significant effect of sleep deprivation on serum $\mathrm{IgG}$ concentrations response to aerobic activity.

Keywords: sleep, deprivation, Immune, IgG, serum, aerobic.

\section{Introduction}

Sleep loss can have profound effects not only on supports immune function but upon human performance [5, 6 , 20, 22, 40]. Many studies indicate that sleep deprivation disrupts cellular immunity [3, 7, 8, 12, 14, 27, 35]. The changes in sleep time across the circadian pattern. Such as during shift work $[1,11,28]$ or air travel (jet-lag syndrome resulting from changing time zones) [41]. As seen in study of Gleeson et al (2007), missing one night of sleep is not uncommon amongst athletes travelling across time zones, recreational athletes with nocturnal work habits and military personnel during training and operations [9]. Several factors such as type, duration, intensity, and program of exercise have also important effects on immune response to exercise [32]. Karacabey et al (2005) showed that aerobic exercise led to changes in immunoglobulin's associated to elevated level of cortisol hormone level [18]. Also, not only in the recent studies of human subjects didn't showed exact mechanism of affecting systemic immunity by sleep or sleep deprivation but also the exercises and Sleep deprivation related studies that have examined changes in immunoglobulin responses are in conflict. Some studies have shown decreases or no change [7, 10, 14, 23, 24, 33, 35]; some have shown increases $[13,30,34$, and 36]. Therefore, the aim of this study was determine the effect of sleep deprivation on serum IgG responses to aerobic activity in college student athletes.

\section{Materials and Methods}

Participants: The subjects were selected randomly among college student athletes who have been training aerobic activities three times a week for 90 minutes each for at least 2 years and volunteered to participate in this study. They gave written informed consent before participating in this investigation and met the following criteria: none smoking; healthy and free of active infection and symptoms; medication-free; no medical history. Descriptive characteristics of the subjects such as weight, body mass index and body fat percentage analysis by using a body composition analysis (ZEUS 9.9, making South Korea). Descriptive characteristics of the subjects are presented in

Table 1.

Descriptive characteristics of the subjects

\begin{tabular}{|c|c|c|c|c|}
\hline & Mean & S.D & Min & Max \\
\hline Age (year) & $21 / 60$ & $1 / 07$ & $20 / 00$ & $24 / 00$ \\
\hline Height $(\mathrm{cm})$ & $177 / 5$ & $6 / 55$ & $169 / 00$ & $192 / 00$ \\
\hline Weight $(\mathrm{kg})$ & $69 / 98$ & $7 / 39$ & $54 / 50$ & $78 / 10$ \\
\hline BMI $\left(\mathrm{kg} / \mathrm{m}^{2}\right)$ & $22 / 22$ & $2 / 00$ & $19 / 10$ & $25 / 00$ \\
\hline Body fat $(\%)$ & $10 / 95$ & $3 / 58$ & $6 / 60$ & $16 / 40$ \\
\hline
\end{tabular}




\section{Sleep protocol}

This research was semi-experimental with two independent occasions which were as follows: the first section is control occasion and the other section is experimental occasion with two weeks interval. Protocol of control occasion have been exerted for eight hours sleeping and in protocol of experimental occasion after two weeks interval (with using games, reading, watching TV and without drinking coffee or tea) sleep deprivation have been exerted for 24-h. Furthermore, all of the athletes had been implicated than keeping regular sleep-wake schedules for at least a week period before entry into the study. Subjects in control occasion had been waked up at 07:30 AM on the day before and following that have been carried out (sleep at 23:30 $\mathrm{PM}^{-}$07:30 $\mathrm{AM}$ ). Aerobic test is taken at 08:00- 08:30 AM. Subjects have been waking up at 07:30 (the day before) to the end of aerobic test at 08:30. Figure 1 illustrates changing patterns of sleep time.

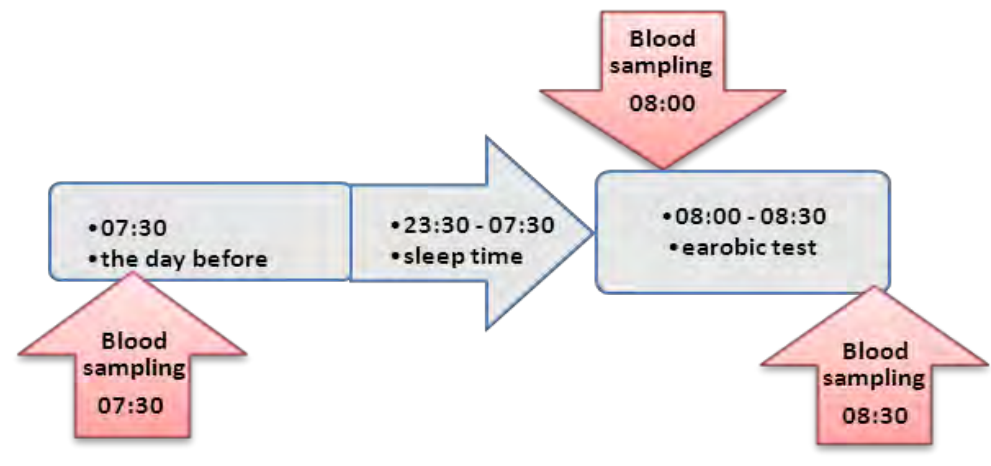

Figure 1: protocol of control occasion

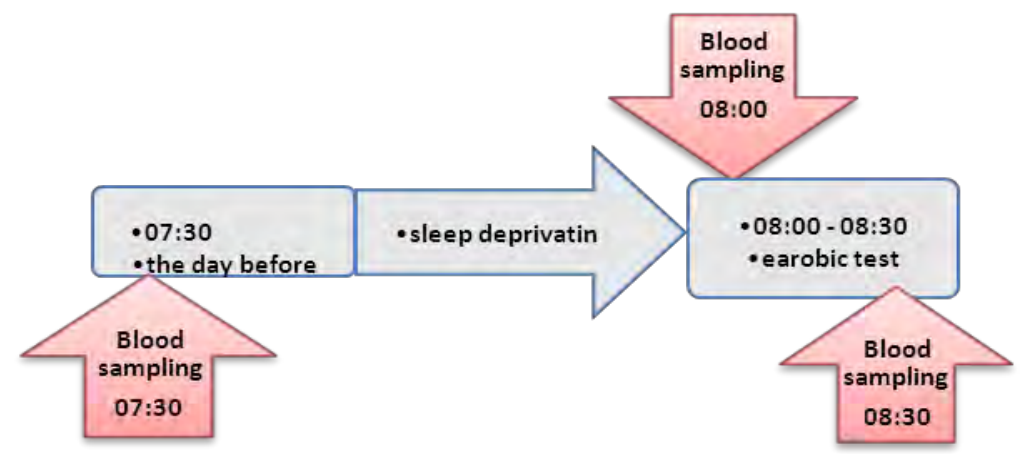

Figure 2: protocol of experimental occasion with two weeks interval

Subjects have received same recipe and they were deprived from napping, used drug and any heavy activities at three days ego. As well as, in the experimental occasion the athletes had been deprived of eat and drink since $24: 00_{\mathrm{pm}}$ forward.

Aerobic activity: aerobic activity was performed on bicycle ergometer (Monark E839 made in Sweden) for 30 minutes. In this case, the subjects first 10 minutes as a warm-up began with 70 watts and 20 minutes with a steady heart rate of 70 to 75 percent of maximum heart rate rode. Speed of $60 \mathrm{rpm}$ was riding across activities. In end three minutes of warm-up occasion, power added until final minute at the end of the stage to warm up, the heart rate reached 70 to 75 percent of maximum heart rate.

\section{Blood sampling}

The blood samples have been collected for three times: a) Pre-test at 08:00 $\mathrm{AM}$ (on the day before), this section of blood sampling were carried out in both of occasions (control and experimental), b) After sleep (control occasion) and sleep deprivation (experimental occasion) at 08:00 $\mathrm{AM}$, c) After aerobic test (Post-test) at 08:30 $\mathrm{AM}$ (in both of occasions). Thus, in this study, blood samples were measured in both of the control occasion and the experimental occasion for six times. Whole blood samples were collected by venepuncture from an antecubital vein $(5 \mathrm{ml})$. Blood samples were placed at room temperature (-70) for 30 minutes to be completely clotted and centrifuged to separate serum. Serum IgG level were measured by using nephelometry which is based on the light scattering properties of antigen-antibody complexes in solution and were used Minineph ${ }^{\mathrm{TM}}$ Human IgG Kit.

\section{Statistical analyses}

Descriptive statistics were used to calculate the mean and standard deviation. The average and standard deviation of data were calculated after checking the data distribution normalcy using Kolmogorov-Smirnov test and two factors of variance analyses method and then examined by repeated measures. As well as, changes in serum IgG concentration in pre-test and post-test were analyzed by dependent t-test using SPSS 18 software at a levels significantly lower than 0.05 $(P<0.05)$ was considered. 


\section{Results}

The results showed that there has not been a meaningful change in IgG levels of athletes during the control occasion. Therefore, aerobic activity not significantly effect on Serum IgG concentration $(p=0.357)$ in Table 2 .

Serum IgG concentration ( $g / l)$ in pre-test and post-test (control occasion)

Table 2

\begin{tabular}{|c|c|c|c|}
\hline $08: 00$ (pre-test) & $08: 30$ (post-test) & $\mathrm{T}$ & $\mathrm{P}^{1}$ \\
\hline $12.08 \pm 2.61$ & $12.55 \pm 1.76$ & -0.970 & 0.357 \\
\hline
\end{tabular}

1 -The mean difference is significant at the $\mathrm{P}<0.05$ level

According to table 3, 24-h sleep deprivation has been a meaningful change in IgG levels of subjects during the experimental occasion. Therefore, aerobic activity had a significant impact on Serum IgG concentration $(p=0.035)$.

Serum IgG concentration $(g / l)$ in pre-test and post-test (experimental occasion)

Table 3

\begin{tabular}{|c|c|c|c|}
\hline $08: 00$ (pre-test) & $08: 30$ (post-test) & $\mathrm{T}$ & $\mathrm{P}^{1}$ \\
\hline $12.05 \pm 2.09$ & $13.57 \pm 3.23$ & -2.476 & $0.035^{*}$ \\
\hline
\end{tabular}

Table 4 and 5 depict there has not been a meaningful change among the effect of sleep deprivation on serum IgG levels responses to aerobic activity in athletes during both of the occasions (control and experimental).

Concentrations of serum $\operatorname{Ig} G(\mathrm{l} / \mathrm{g})$ at the pre and post test in both of occasions
\begin{tabular}{|l|l|l|}
\hline & Pre-test & Post-test \\
\hline Sleep & $11.60 \pm 2.174$ & $10.80 \pm 1.557$ \\
\hline Sleep deprivation & $12.60 \pm 2.481$ & $08.85 \pm 1.904$ \\
\hline
\end{tabular}

Table 4

Two factors of variance analyses and repeated measure

Table 5

\begin{tabular}{|l|c|c|}
\hline & F & P \\
\hline Sleep & 0.986 & 0.746 \\
\hline Sleep deprivation & 5.364 & 0.045 \\
\hline Sleep $\times$ aerobic activity & 2.772 & 0.130 \\
\hline
\end{tabular}

\section{Discussion}

In this study was observed 30 minutes sub maximal aerobic exercise on a bicycle ergometer no significantly effect on serum IgG concentration. Generally in exercise immunology, a raise in immunoglobulin level has usually been interpreted to represent increased immunity, and a decrease is usually explained as immunosuppression (Mackinnon, 1999) [25]. In this case, Poortmans (1979) found a significant $12 \%$ increase in serum $\operatorname{IgG}$ immediately after a progressive cycle ergometer test to fatigue (mean duration 21 minutes) [37]. These results are inconsistent with the findings of this study that may it was been because of performance style, time during or intensity. Nieman and NehlsenCannarella (1991) found that IgG decreased during recovery after a three hour run at marathon, reaching its lowest point at one and half hours (27.6 percent) and increasing to baseline concentration 21 hours after exercise [34], Poortmans and Haralambie (1979) reported a significant 7\% increase in IgG immediately after a $100 \mathrm{~km}$ race. In contrast with, Israel et al. (1982) reported that 25 hours after a $75 \mathrm{~km}$ run at high intensity, IgG was decreased by $22 \%$. Exercise induced decreases in IgG have been reported [16]. Mashiko et al. (2004) found a significant decrease in IgG (28\%) after a 20 day rugby exercise, exercise six days a week with 2 hours a day [26]. Results of this study, however, is approximately consistent with the research of Karacabey et al (2005) that suggesting the no significantly change in the level of serum IgG concentration after aerobic exercise [18]. As an example, Subjects in the Ganga study were marathon runners, their mean activity duration was 2.7 hour but activity duration in the present study was 30 minutes. As well as, intensity of activity in Ganga study was maximal but intensity of activity in the present study was sub maximal (70 to 75 percent of maximum heart rate) [10]. Aerobic activity in Karacabey study was 30 minutes running on treadmill with intensity 60 to 70 percent of maximal oxygen uptake that is very similar to the present study in terms of intensity and duration [18]. Factors like type, duration, intensity, and program of the exercise and the use of different subjects, various complex mechanisms including hormonal, metabolic and psychoneural stress are also known to have effects on the immune system and discrepancy between this study and other studies[32]. According to the conducted studies, it has been determined that body activities are one of the effective factors in changing of immune system process, which depends on the intensity, time, training plan, and body athleticism. This study concludes that sub maximal aerobic activity does not affect on serum IgG concentration. The findings in this study also indicated that sleep deprivation have affected on serum IgG concentration while none affect on serum IgG responds to aerobic activity at least in same intensity that we employed. The data deriving from the human studies are inconsistent or contradictory [7, 17]. While it is evident that sleep loss exerts an influence on the immune system [2], it remains unclear whether the influence is beneficial or detrimental. The present studies also show that sleep loss influences the measure of cellular 
immunity and B-cell immunity and alters the nocturnal secretion of the proinflammatory cytokines such as IL-6 [38, 15]. IgG, IgA and IgM concentrations were found to increase after 24-hour wakefulness [13], Boyum et al showed that sleep deprivation decreased the level of human immunoglobulins [4]. We didn't find any study that had been surveyed the effect of sleep deprivation on serum IgG responses to exercise and we hadn't resources for comparing this study with those as well. However, we concluded that sleep deprivation on serum IgG didn't respond to aerobic activity, although probable mechanism the effect of sleep deprivation on immunoglobulins to aerobic activity is still unclear. We also concluded that Sleep deprivation increase IgG concentration at $70-75 \% \mathrm{HR}_{\max }$.

Acknowledgements and Financial Disclosure

We are grateful to all participants of the protocol and to Mr Mirza Hossein Norouzi because of data collocations. We are also thankful by the Research department of Razi University. This study was funded by the Research department of Razi University.

\section{References}

1. Akerstedt T. Shift work and disturbed sleep/wakefulness. Sleep Med Rev. 1998, vol 2, pp.117-128.

2. Bentivoglio M., Kristensson K. Neural-immune interactions in disorders of sleep-wakefulness organization. Trends Neurosci. 2007, vol 30, pp. 645-52.

3. Born J., Lange T., Hansen K., Mölle M., Fehm H.L. Effects of sleep and circadian rhythm on human circulating immune cells. Journal of Immunology. 1997, vol.158, pp. 4454-4464.

4. Boyum A., Wiik P., Gustavsson E., Veiby O. P., Reseland J., Haugen A. H., Opstad P. K. The effect of strenuous exercise, calorie deficiency and sleep deprivation on white blood cells, plasma immunoglobulins and cytokines. Scandinavian Journal of Immunology. 1996, vol.43, pp. 228-235.

5. Bryant P.A., Trinder J., Curtis N. Sick and tired: Does sleep have a vital role in the immune system? Nature Reviews Immunology. 2004, vol.4, pp. 457-467.

6. Cohen S., Doyle W.J., Alper C.M., Janicki-Deverts D., Turner R.B. Sleep habits and susceptibility to the common cold. Archives of Internal Medicine. 2009, vol.169, pp. 62-67.

7. Dinges D.F., Douglas S.D., Hamarman S., Zaugg L., Kapoor S. Sleep deprivation and human immune function. Advances in Neuroimmunology. 1995, vol.5, pp. 97-110.

8. Fondell E., Axelsson J., Franck K., Ploner A., Lekander M. Short natural sleep is associated with higher T cell and lower NK cell activities. Brain Behavior and Immunity. 2011, vol.25, pp. 1367-75.

9. Gleeson M. Immune functions in sport and exercise. Journal of Applied Physiology. 2007, vol.10, pp. 693-699.

10. Gunga H.C., Machotta A., Schobersberger W., Mittermayr M., Kirsch K., Koralewski E. Neopterin, IgG, IgA, IgM, and Plasma Volume Changes During Long-distance Running. Pteridines. 2002, vol.13, pp. 13-20.

11. Harma M., Hakola T., Kandolin I., Sallinen M., Virkkala J., Bonnefond A. A controlled intervention study on the effects of a very rapidly forward rotating shift system on sleep- wakefulness and well-being among young and elderly shift workers. International Journal of Psychophysiology. 2006, vol.59, pp. 70-79.

12. Heiser P., Dickhaus B., Schreiber W., Clement H.W., Hasse C. White blood cells and cortisol after sleep deprivation and recovery sleep in humans. European Archives of Psychiatry and Clinical Neuroscience. 2000, vol.25, pp. 16-23.

13. Hui L., Hua F., Diandong H., Hong Y. Effects of sleep and sleep deprivation on immunoglobulins and complement in humans. Brain Behavior and Immunity. 2007, vol.21, pp. 308-310.

14. Irwin M., McClintick J., Costlow C., Fortner M., White J. Partial night sleep deprivation reduces natural killer and cellular immune responses in humans. FASEB Journal. 1996, vol.10, pp. 643-653.

15. Irwin M. Immune correlates of depression. Advances in Experimental Medicine and Biology. 1999, vol.46, pp. 124.

16. Israel S., Buhl B., Neumann G. Die konzentration der immunoglobulin A, G und M im serum bei trainierten und untrainierten sowie nach verschiedenen sportlicken ausdauerleistungen. Sports Medicine (Berlin). 1982, vol.22, pp. 225-231.

17. Jurkowski M.K., Bobek-Billewicz B. Influence of sleep deprivation on immunity. Studies in Ethnicity and Nationalism. 2002, vol.2, pp. 95-98.

18. Karacabey K., Peker I., Saygm O., Ciloglu F., Ozmerdivenli R., Bulut V. Effects of Acute Aerobic and Anaerobic Exercise on Humoral Immune Factors in Elite Athletes. Biotechnology \& Biotechnological Equipment. 2005, vol.19, pp. 175-180.

19. Karacabey K., Saygin O., Ozmerdivenli R., Zorba E., Godekmerdan A., Bulut V. The effects of exercise on the immune system and stress hormones in sportwomen. Neuroendocrinology Letters. 2005, vol.26, pp. 361-366.

20. Killgore W.D., Killgore D.B., Day L.M. The effects of 53 hours of sleep deprivation on moral judgment. Sleep. 2007, vol.30, pp. 345-352.

21. Kwarecki K., Zużewicz K. Patterns of sleep and locomotor activity in shift workers with special reference to night shift. Medycyna pracy. 2002, vol.53, pp. 79-84.

22. Lim J., Dinges D.F. Sleep deprivation and vigilant attention. Annals of the New York Academy of Sciences. 2008, vol.29, pp. 305-322.

23. Mackinnon L.T., Hooper S.L. Mucosal (secretory) immune system responses to exercise of varying intensity and during overtraining. International Journal of Sports Medicine. 1994, vol.15, pp. 179-183. 
24. Mashiko T., Umeda T., Nakaji S. Effects of exercise on the physical condition of college rugby players during summer training camp. British Journal of Sports Medicine. 2004, vol.38, pp. 186-190.

25. Mackinnon L.T. Immunoglobulin, antibody, and exercise. Exercise Immunology Review. 1996; vol.35, pp. 21-35.

26. Mashiko T., Umeda T., Nakaji S. Effects of exercise on the physical condition of college rugby players during summer exercise camp. British Journal of Sports Medicine. 2004, vol.38, pp. 186-190.

27. Moldofsky H, Lue FA, Davidson JR, Gorczynski R. Effects of sleep deprivation on human immune functions. FASEB Journal. 1989, vol.3, pp. 1972-1977.

28. Monk T.H., Welsh D.K. The role of chronobiology in sleep disorders medicine. Sleep Medicine Reviews. 2003, vol.7, pp. 455-473.

29. Mullington J.M., Simpson N.S., Meier-Ewert H.K., Haack M. Sleep loss and inflammation. Best Practice \& Research Clinical Endocrinology \& Metabolism. 2010, vol.24, pp. 775-784.

30. Nehlsen-Cannarella S.L., Nieman D.C., Jessen J. The effects of acute moderate exercise on lymphocyte function and serum immunoglobulin levels. International Journal of Sports Medicine. 1991, vol.12, pp. 391-398.

31. Gunga H-C., Machotta A., Schobersberger W. Neopterin, IgG, IgA, IgM, and Plasma Volume Changes During Long-distance Running. Pteridines. 2002, vol.13, pp.13-20. doi:10.1515/pteridines.2002.13.1.15

32. Nieman D., Miller A., Henson D., Warren B., Gusewitch G., Johnson R. Effects of high- vs moderateintensity exercise on natural killer cell activity. Medicine \& Science in Sports \& Exercise. 1993, vol.25, pp. 1126-1134.

33. Nieman D.C., Tan S.A., Lee J.W. Complement and immunoglobulin levels in athletes and sedentary controls. International Journal of Sports Medicine. 1989, vol.10, pp. 124-128.

34. Nieman D.C., Nehlsen-Cannarella S.L. The effects of acute and chronic exercise and immunoglobulins. Sports Medicine. 1991, vol.11, pp. 183-201.

35. Oztürk L., Pelin Z., Karadeniz D., Kaynak H., Cakar L. Effects of 48 hours sleep deprivation on human immune profile. Sleep Research, 1999, vol.2, pp. 107-111.

36. Petibois C., Cazorla G., Deleris G. The biological and metabolic adaptations to 12 months training in elite rowers. International Journal of Sports Medicine. 2003, vol.24, pp. 36-42.

37. Poortmans J., Haralambie G. Biochemical changes in a $100 \mathrm{~km}$ run: proteins in serum and urine. European Journal of Physiology, 1979, vol.40, pp. 245-254.

38. Renwine L., Hauger R.L., Gilln J.C., Irwin M. Effects of sleep and sleep deprivation on interleukin-6, growth hormone, cortisol, and melatonin levels in humans. Journal of Clinical Endocrinology \& Metabolism. 2000, vol.85, pp. 3597-3603.

39. Ruiz F.S., Andersen M.L., Martins R.C., Zager A., Lopes J.D., Tufik S. Immune alterations after selective rapid eye movement or total sleep deprivation in healthy male volunteers. Innate Immunity. 2012, vol.18, pp. 44-54.

40. Taheri M., Arabamery M. The effect of sleep deprivation on choice reaction time and anaerobic power of college student athletes. Asian Journal of Sports Medicine, 2012, vol.3, pp. 15-20.

41. Tamagawa R., Lobb B., Booth R. Tolerance of shift work. Applied Ergonomics. 2007, vol.38, pp. 635-642. 
Information about the authors:

Saeed Jamshidi Far: ORCID: http://orcid.org/0000-0002-7761-4356; saeedjamshidifar@yahoo.com; University of Guilan; P.O Box 1438, Rasht, Iran.

Mirza Hossein Norouzi Kamareh: ORCID: http://orcid.org/0000-0002 3900-0521; mirzahoseynnorozi@yahoo.com; University of Urmia; P.O Box 1027, Urmia, Iran.

Cite this article as: Saeed Jamshidi Far, Mirza Hossein Norouzi Kamareh. The effect of sleep deprivation on serum igg responses to aerobic activity in college student athletes. Physical education of students, 2014, vol.6, pp. 90-95. doi:10.15561/20755279.2014.0617

The electronic version of this article is the complete one and can be found online at: http://www.sportpedu.org.ua/html/arhive-e.html

This is an Open Access article distributed under the terms of the Creative Commons Attribution License, which permits unrestricted use, distribution, and reproduction in any medium, provided the original work is properly cited (http:// creativecommons.org/licenses/by/3.0/deed.en).

Received: 10.06.2014

Published: 30.06 .2014 